\title{
Carbohydrate source and protein degradability alter lactation, ruminal, and blood measures ${ }^{1,2}$
}

\author{
M. B. Hall, ${ }^{*}$ C. C. Larson, $\dagger$ and C. J. Wilcox $†$ \\ *US Dairy Forage Research Center, USDA-ARS, Madison, WI 53706 \\ †Department of Animal Sciences, University of Florida, Gainesville 32611
}

\begin{abstract}
Thirty-eight lactating dairy cows including 6 ruminally cannulated cows were used in a feeding study to assess effects of feed sources that differed in dietary nonfiber carbohydrate (NFC) composition and ruminal degradability of dietary protein (RDP) on production, ruminal, and plasma measures. The design was a partially balanced, incomplete Latin square with three 21 -d periods and a $3 \times 2$ factorial arrangement of treatments. Samples and data were collected in the last 7 $\mathrm{d}$ of each period. Feed sources that differed in NFC profile were dry ground corn (GC; starch), dried citrus pulp (DCP; sugar and pectins), and sucrose+molasses (SM; sugar). Dietary RDP was altered by providing $\mathrm{CP}$ with soybean meal (+RDP) or substituting a heattreated expeller soybean product for a portion of the soybean meal (-RDP). Diets were formulated to be isonitrogenous and similar in NFC concentration. Cows consuming GC had the greatest milk urea nitrogen and milk protein percentage and yield, tended to have the greatest dry matter intake, but had a lesser milk fat percentage compared with cows consuming DCP and SM. Sucrose+molasses diets supported greater dry matter intake, milk protein yield, and $3.5 \%$ fat- and protein-corrected milk yield than did DCP diets. On -RDP diets, milk protein percentage was less and milk urea nitrogen and protein yield tended to be less than for $+\mathrm{RDP}$ diets. Dry ground corn diverged from $\mathrm{DCP}$ and $\mathrm{SM}$ in the effect of NFC $\times \mathrm{RDP}$, with cows consuming GC having lesser milk yield, $3.5 \%$ fat- and protein-corrected milk yield, and efficiency with -RDP as compared with $+\mathrm{RDP}$, whereas these production measures were greater with $-\mathrm{RDP}$ than $+\mathrm{RDP}$ for cows consuming DCP and SM. In contrast, in situ NDF
\end{abstract}

\footnotetext{
Received July 7, 2009.

Accepted October 5, 2009.

${ }^{1}$ This research was supported by the Florida Agricultural Experiment Station and a grant from the Florida Milk Check-Off.

${ }^{2}$ Mention of any trademark or proprietary product in this paper does not constitute a guarantee or warranty of the product by the USDA or the Agricultural Research Service and does not imply its approval to the exclusion of other products that also may be suitable.

${ }^{3}$ Corresponding author: marybeth.hall@ars.usda.gov
}

digestibility at $30 \mathrm{~h}$ for $\mathrm{GC}$ and $\mathrm{SM}$ was greater for $-\mathrm{RDP}$ as compared with $+\mathrm{RDP}$, but the reverse was true for DCP. The lowest ruminal $\mathrm{pH}$ detected by $6 \mathrm{~h}$ postfeeding was also influenced by the interaction of NFC $\times$ RDP, with cows consuming SM having a lower $\mathrm{pH}$ with $+\mathrm{RDP}$ than with $-\mathrm{RDP}$ and cows consuming DCP having a similar $\mathrm{pH}$ on either RDP treatment. Total rumen volatile fatty acid concentrations did not differ among diets, but acetate molar percent was greater for DCP than for SM, and GC had the lowest molar percent for butyrate and valerate and greatest branched-chain volatile fatty acid concentration. Valerate molar percent and $\mathrm{NH}_{3}$ concentration tended to be greater with $+\mathrm{RDP}$ than with $-\mathrm{RDP}$. Plasma glucose and insulin were both greater in cows receiving SM than in those receiving DCP. Protein degradability, NFC source, and their interactions affected lactation, ruminal, and blood measures, suggesting that these dietary factors warrant further consideration in diet formulation.

Key words: nonfiber carbohydrate, protein degradability, dairy cow, by-product feed

\section{INTRODUCTION}

Dietary carbohydrate is composed of fiber (NDF) and nonfiber (NFC) fractions, which collectively compose 65 to $75 \%$ of the diets of lactating dairy cattle. Nonfiber carbohydrates may provide 30 to $45 \%$ of the diet on a DM basis. Although NFC has been represented as a single value for feeds or diets, the types of carbohydrates in this fraction can vary greatly. For example, the NFC in corn grain is mostly starch $(65$ to $70 \%$ of DM), citrus pulp provides sugars (12 to $40 \%$ of DM), and neutral detergent-soluble fiber (NDSF; largely pectic substances; 25 to $44 \%$ of DM) and sugars (mono- and disaccharides) are predominant in molasses (Hall, 2002). The dietary profile of NFC has the potential to alter the supply of metabolizable nutrients to the animal because NFC differ in digestion and fermentation characteristics. In vitro fermentation of sucrose, starch, and pectin resulted in different organic acid profiles (Strobel and Russell, 1986), and maximal 
microbial protein yields (Hall and Herejk, 2001). The NFC are also dissimilar in small intestinal digestion characteristics; monosaccharides, maltose, sucrose, lactose, and starch have the potential to be digested by mammalian enzymes in the small intestine, depending on the species, whereas pectic substances and other nonstarch polysaccharides in NDSF are not digested.

Perhaps because of differences in digestion characteristics and products, the NFC complement of the diet has the potential to alter feed intake, milk production, and composition of milk, but the results have varied. Dietary substitution of feeds with greater contents of pectin for starchy feeds has increased intake (Lees et al., 1990; Valk et al., 1990; Chester-Jones et al., 1991) and decreased milk yield (Van Horn et al., 1975; Leiva et al., 2000; Broderick et al., 2002b) and yield and percentage of milk protein (Mansfield et al., 1994; Leiva et al., 2000; Solomon et al., 2000; Broderick et al., 2002b). With the diets with more pectin, milk fat percentage was increased (Van Horn et al., 1975; Lees et al., 1990; Mansfield et al., 1994) or remained unchanged (Leiva et al., 2000; Solomon et al., 2000). Supplementation of sugars in place of starchy feeds decreased milk protein percentage (Nombekela and Murphy, 1995) and yield (Sannes et al., 2002). Still other studies reported no difference in intake or production as the dietary NFC profile changed (Malestein et al., 1984; Fegeros et al., 1995).

The objective of this study was to evaluate the effects of feed sources differing in the complement of dietary NFC at greater or lesser dietary concentrations of RDP on lactation, blood, and ruminal measures.

\section{MATERIALS AND METHODS}

\section{Cows, Diets, and Facilities}

The experiment was conducted at the University of Florida Dairy Research Unit, Hague, Florida, from January through March 2002. Thirty-eight multiparous Holstein cows (82 DIM, SD $=19$; average $\mathrm{BW}=614 \mathrm{~kg}$, $\mathrm{SD}=56)$, including 6 ruminally cannulated animals (10 cm i.d., Bar Diamond Inc., Parma, ID), were randomly assigned to series of dietary treatments in a partially balanced, incomplete Latin square design with a $3 \times$ 2 factorial arrangement of treatments and 3 periods. With 3 treatments per series to allow one treatment per period, the set of 32 series of treatments was designed so that each treatment followed every other treatment including itself. Cannulated cows were assigned with a specific subset of series in which each treatment did follow every other treatment, but no treatment followed itself. The periods were $21 \mathrm{~d}$ in length, with $14 \mathrm{~d}$ for acclimation and $7 \mathrm{~d}$ for sample collection. Period 2 was restarted after an initial $14 \mathrm{~d}$ on feed because of technical difficulties with the feeding system.

Cows were housed in an open-sided, freestall barn bedded with sand and equipped with fans and misters. Cows were fed individually with diets offered in ad libitum amounts twice daily (at 0600 and $1300 \mathrm{~h}$ ) through Calan gates (American Calan, Northwood, NH) and milked 3 times daily at 0500, 1300, and $2100 \mathrm{~h}$. Body weights were recorded after morning milking on d 15, 17, and 19 of each period. Animals were maintained under protocols approved by the University of Florida Institutional Animal Care and Use Committee. Because of health disorders not related to the study, one of the cannulated cows was removed from the study in the third period and was not used for any sampling in that period.

The feed sources used to modify dietary NFC supply were dry ground corn (GC; supplied starch), dried citrus pulp (DCP; supplied NDSF and sugar), and liquid molasses and sucrose (SM; supplied sugar). The 2 treatments differing in dietary concentrations of RDP were achieved by supplementing with $48 \%$ soybean meal $(+\mathbf{R D P})$ or with a combination of expeller soybean meal (SoyPLUS, West Central Soy, Ralston, IA) and $48 \%$ soybean meal (-RDP). All diets were formulated to contain similar basal concentrations of forage (corn silage and sorghum silage), to be isonitrogenous, and to contain similar concentrations of total NFC and NDF (Table 1). The small variation noted among diets in measured CP concentrations in TMR samples collected daily from the feed bunks of the individual cows might be related to issues in subsampling the TMR at the feed bunk and analysis of the feeds (see the following discussion on sample analysis).

\section{Sample Collection and Analysis}

Amounts of diets fed and refused were recorded daily, with subsamples of the TMR and orts obtained for each cow during the 7-d collection phase of each period. Samples were frozen at $-20^{\circ} \mathrm{C}$ until analysis. Subsamples of TMR and orts for individual cows collected each day during the sampling period were analyzed for $\mathrm{DM}$ at $105^{\circ} \mathrm{C}$, with samples dried in a forced-air oven until they reached a constant weight. Daily DMI was calculated for each animal as the difference on a DM basis between weights of feed offered and orts collected. The remainders of the TMR samples were dried at $55^{\circ} \mathrm{C}$ in a forced-air oven, ground to pass the 1-mm screen of a Wiley mill (Arthur H. Thomas Co., Philadelphia, PA), and composited by cow by period.

Lint from cottonseed products in the TMR made the ground samples nonhomogenous and impossible to subsample accurately for analysis, giving analytical values 
Table 1. Ration composition

\begin{tabular}{|c|c|c|c|c|c|c|}
\hline \multirow[b]{2}{*}{ Item } & \multicolumn{2}{|c|}{ Ground corn } & \multicolumn{2}{|c|}{ Citrus pulp } & \multicolumn{2}{|c|}{ Molasses+sucrose } \\
\hline & $+\mathrm{RDP}^{1}$ & $-\mathrm{RDP}^{1}$ & $+\mathrm{RDP}$ & $-\mathrm{RDP}$ & $+\mathrm{RDP}$ & $-\mathrm{RDP}$ \\
\hline \multicolumn{7}{|c|}{ Ingredient or fraction, $\%$ of diet DM } \\
\hline Corn silage & 25.9 & 25.7 & 25.6 & 25.2 & 26.2 & 25.9 \\
\hline Sorghum silage & 11.9 & 11.8 & 11.7 & 11.6 & 12.0 & 11.9 \\
\hline Cottonseed hulls & 3.9 & 3.8 & 3.9 & 3.8 & 3.9 & 3.9 \\
\hline Whole cottonseed & 13.6 & 13.3 & 13.6 & 13.4 & 13.8 & 13.5 \\
\hline $48 \%$ soybean meal & 14.6 & 5.8 & 15.8 & 6.4 & 16.6 & 6.7 \\
\hline SoyPLUS $^{2}$ & - & 9.7 & - & 10.5 & - & 10.9 \\
\hline Ground corn & 20.9 & 20.7 & 3.8 & 3.8 & 1.9 & 1.9 \\
\hline Citrus pulp & 3.8 & 3.8 & 20.7 & 20.4 & 9.8 & 9.7 \\
\hline Molasses & - & - & - & - & 7.1 & 7.1 \\
\hline Sucrose & - & - & - & - & 3.3 & 3.2 \\
\hline Limestone & 1.2 & 1.3 & 0.6 & 0.7 & 1.1 & 1.1 \\
\hline Mineral mix & 4.2 & 4.2 & 4.3 & 4.2 & 4.3 & 4.3 \\
\hline \multicolumn{7}{|c|}{ Component, ${ }^{3} \%$ of diet DM } \\
\hline $\mathrm{CP}$ & 16.9 & 16.9 & 17.5 & 16.9 & 17.9 & 17.4 \\
\hline $\mathrm{NDF}$ & 32.0 & 33.0 & 33.7 & 34.4 & 31.3 & 32.0 \\
\hline ESC & 3.4 & 3.5 & 6.3 & 6.5 & 11.8 & 12.1 \\
\hline Starch & 23.6 & 24.1 & 14.2 & 13.5 & 12.2 & 12.6 \\
\hline NDSF & 14.4 & 14.1 & 19.3 & 18.2 & 16.7 & 15.2 \\
\hline Sum of $\mathrm{NFC}^{4}$ & 41.4 & 41.7 & 39.7 & 38.2 & 40.6 & 39.9 \\
\hline Ash & 7.8 & 7.4 & 8.3 & 7.8 & 8.9 & 8.3 \\
\hline
\end{tabular}

that bore no resemblance to the diets as formulated or that represented diets likely to have supported the milk production recorded in this study (e.g., for diet GC-RDP: $15.4 \% \mathrm{CP}$ and $39.6 \% \mathrm{NDF}$, DM basis). We determined that the method most likely to give an accurate representation of the TMR chemical composition was sieving of the composited samples, analysis of separated lint and nonlint fractions, and calculation of the diet composition based on the analyses and proportions of lint and nonlint material. The small amount of lint (2 to $6 \%$ of TMR DM) in composited TMR samples from individual cows (total 50 to $60 \mathrm{~g}$ ) precluded obtaining enough lint to run the chemical analyses on nonlint and lint fractions on the individual cow-period composites. Composites of TMR by period were made for each of the treatment diets by tumbling/mixing each cowperiod TMR composite thoroughly on a large piece of paper, dividing the sample in half, and including half of the sample ( 25 to $30 \mathrm{~g}$ ) in a diet-by-period composite. The diet-by-period composite samples were then sieved through a \#16 USA Standard testing sieve with 1.18mm openings (ATM Corp., Milwaukee, WI) to separate lint that remained on the sieve from the largely nonlint remainder of the feed. Lint and nonlint fractions were weighed, and their proportions in each TMR in each period were determined on a DM basis. The lint and nonlint fractions of the composited TMR samples were analyzed for $\mathrm{DM}\left(105^{\circ} \mathrm{C}\right.$ for $\left.8 \mathrm{~h}\right)$ and $\mathrm{OM}\left(512^{\circ} \mathrm{C}\right.$ for 8 h), NDF, CP, and NFC constituents. Neutral detergent fiber was measured using heat-stable, $\alpha$-amylase (Multifect AA 21L, Genencor International, Rochester, NY; Goering and Van Soest, 1970; Van Soest et al., 1991) and was not corrected for ash content to retain samples for further analysis. Starch was analyzed by a modification of the method of Bach Knudsen (1997) that used 100 units per sample of amyloglucosidase and omitted the 10 -min incubation at $100^{\circ} \mathrm{C}$ after enzyme treatments were complete. The $80 \%$ ethanol-soluble carbohydrate (used as a proxy for sugar content) and NDSF contents of the feed and orts were determined as described by Hall et al. (1999). Crude protein concentration as N $\times 6.25$ of composited samples, ethanol-insoluble residues, and neutral detergent residues was determined by combustion analysis (Dumas combustion method, VarioMax CN, Elementar Americas Inc., Mt. Laurel, NJ). The composition of the TMR was calculated according to the proportions and chemical analyses of the lint and nonlint fractions for each sample. The values for each diet from each period were averaged to give the average diet compositions for the study (Table 1).

Samples of soybean meal and SoyPLUS used for the study were analyzed with an in vitro protein degradability assay (Broderick et al., 2004) to verify that they differed in their relative degradability by ruminal microbes. The rates of fermentation were 7.8 and $4.4 \%$ per hour for the soybean meal and SoyPLUS, respectively, 
suggesting that these feed would differ in their ruminal degradability.

Milk weights were recorded for all milkings during the collection period and samples collected from all milkings on d 15, 17, and 19 of each period. All milk samples were analyzed by Lancaster DHIA Labs (Lancaster, PA) for fat and protein using mid-infrared technology (B-2000, Bentley Instruments, Chaska, $\mathrm{MN}$ ) and for MUN using an enzymatic and colorimetric method (Chemspec 150, Bentley Instruments). Somatic cell count was measured by laser counting technology (Somacount 500, Bentley Instruments). Production of $3.5 \%$ fat- and protein-corrected milk $(3.5 \%$ FPCM $)$ was calculated by the following equation (derived from Tyrrell and Reid, 1965):

$$
\begin{gathered}
3.5 \% \text { FPCM }(\mathrm{kg} / \mathrm{d})=[12.82 \times \text { fat }(\mathrm{kg} / \mathrm{d})] \\
+[7.13 \times \text { protein }(\mathrm{kg} / \mathrm{d})]+[0.323 \times \text { milk }(\mathrm{kg} / \mathrm{d})] .
\end{gathered}
$$

Feed efficiency was calculated as 3.5\% FPCM divided by DMI.

The concentration of $\mathrm{NE}_{\mathrm{L}}$ per unit of $\mathrm{DMI}$ was estimated by the following equation (NRC, 2001) with all milk measures expressed in terms of per cow per day:

$$
\begin{gathered}
\mathrm{NE}_{\mathrm{L}}(\text { Mcal } / \mathrm{kg} \text { of DMI })=\left\{\left[0.08 \times \mathrm{BW}^{0.75}(\mathrm{~kg})\right]\right. \\
+\{[0.0929 \times \text { milk fat }(\%)]+[0.0547 \times \text { milk } \mathrm{CP}(\%)] \\
+0.192\} \times \text { milk }(\mathrm{kg})\} / \mathrm{DMI}(\mathrm{kg}) .
\end{gathered}
$$

It was assumed that energy requirements for growth, reproduction, and repletion of reserves were minor contributors to energy demands of the cattle in this study.

Blood samples $(\sim 10 \mathrm{~mL})$ were collected on d 15 and 17 of each period by coccygeal venipuncture into Vacutainer tubes containing sodium heparin (Becton Dickinson, Franklin Lakes, NJ), which were immediately placed on ice. Duplicate samples were transferred into capillary tubes and centrifuged in a microcapillary centrifuge (MB Centrifuge, I.E.C., Needham Heights, MA) to determine hematocrit and plasma protein. Hematocrit values were measured on whole blood with a Damon microcapillary reader (Cat. No. 2201, I.E.C.). Plasma protein content was measured on hematocrit samples using a refractometer (Schuco Model 57112020, Williston Park, NY). The remaining samples in Vacutainer tubes were centrifuged at $1,916 \times g$ for 30 min at $5^{\circ} \mathrm{C}$ to separate plasma, which was transferred to vials and frozen at $-20^{\circ} \mathrm{C}$ until analysis.

An autoanalyzer (Technicon Instruments Corp., Chauncey, NY) was used to measure plasma urea N (a modification of Marsh et al., 1965, as described in Bran and Luebbe Industrial Method \#339-01) and plasma glucose (a modification of Gochman and Schmitz, 1972, as described in Bran and Luebbe Industrial Method \#339-19). Plasma insulin was analyzed with a double antibody radioimmunoassay procedure described by Soeldner and Slone (1965) and modified by Malven et al. (1987). A Packard auto gamma counter (model B-5005, Packard Instrument Co. Inc., Downers Grove, IL) measured bound radioactivity in tubes.

\section{In Situ Ruminal Incubations}

Extent of NDF disappearance of sorghum silage was measured in situ on d 16, 17, and 18 of each period (Nocek, 1988) using the ruminally cannulated cows. Approximately $5.0 \mathrm{~g}$ (air dry) of dried sorghum silage ground to pass a $2-\mathrm{mm}$ screen (Wiley mill) was weighed into preweighed polyester bags $(10 \times 20 \mathrm{~cm}$, average pore size of $53 \pm 10 \mu \mathrm{m}$; Bar Diamond Inc., Parma, ID). Duplicate bags for each hour were inserted into a weighted $(\sim 1 \mathrm{~kg})$ nylon mesh bag, which was inserted into the rumen via the rumen cannula, at intervals of $0,24,30$, and $48 \mathrm{~h}$. All bags were removed simultaneously. Following removal, bags were submerged in cold water and rinsed continuously until the water ran clear. Bags were then rinsed in a washing machine on the delicate/cold cycle, dried in a forced-air oven at $55^{\circ} \mathrm{C}$ for $48 \mathrm{~h}$, and weighed to determine DM residue. The residue was analyzed for NDF (OM basis; Goering and Van Soest, 1970; Van Soest et al., 1991) using heatstable, $\alpha$-amylase. The potentially digestible fraction and rate of disappearance of the sorghum silage could not be determined because the curve describing sample disappearance did not plateau by the end of the 48-h incubation period. Consequently, in situ disappearance of NDF was compared among treatments within sampling hour. Values for duplicate bags at a sampling hour within cow were averaged for use in the statistical analysis.

\section{Ruminal Fluid Sampling and Analysis}

Ruminal fluid samples were collected via ruminal cannulas from the 6 ruminally cannulated cows on d 20 of each period. Starting before feeding and continuing hourly for the next $12 \mathrm{~h}$, ruminal fluid (total of $\sim 500$ $\mathrm{mL}$ ) was collected from the cranial, ventral, and caudal areas of the rumen. Samples were immediately capped, inverted to mix, and $\mathrm{pH}$ measured with an electronic pH meter (Accumet Model 15, Fisher Scientific, Pittsburgh, PA). For each sample, a subsample of $40 \mathrm{~mL}$ was acidified with $1 \mathrm{~mL}$ of $50 \%$ sulfuric acid and centrifuged at $5,400 \times g$ for $20 \mathrm{~min}$ at $5^{\circ} \mathrm{C}$. The supernatant 
was frozen at $-20^{\circ} \mathrm{C}$ until analysis. For VFA analysis, rumen fluid samples were thawed at room temperature (approximately $23^{\circ} \mathrm{C}$ ) and centrifuged at $5,000 \times g$ for 30 min and filtered with a high-affinity protein syringedriven filter unit (Millex SLAA025LS, Fisher Scientific, Pittsburg, PA). Prepared samples were analyzed by gas chromatography (4\% carbomax 80/120 BDA column, Supelco Inc., Bellefonte, PA; Autosystem XL gas chromatograph, Perkin Elmer Inc., Norwalk, CT) with the chromatograph set to a flow rate of $30 \mathrm{~mL} / \mathrm{min}$ of $\mathrm{N}$, an injection port temperature of $200^{\circ} \mathrm{C}$, oven temperature of $190^{\circ} \mathrm{C}$, and the flame ionizing detector at $450^{\circ} \mathrm{C}$. The rumen fluid samples were analyzed for AA concentration (as leucine equivalents) and ammonia by the method of Broderick et al. (2004) using flow injection (Lachat Quik-Chem 8000 FIA, Lachat Instruments, Milwaukee, WI). Total VFA was calculated as the sum of the millimolar values for acetate, propionate, butyrate, and valerate, with total carbon in the VFA calculated by multiplying the millimolar concentrations of VFA by 2 , 3,4 , and 5 , respectively.

\section{Statistical Analysis}

Variables used in the statistical analyses were $Y=$ the dependent variable, $\mu=$ overall mean, $C_{i}=$ cow $(i=1, \ldots, 38), P_{j}=\operatorname{period}(j=1,2,3), N_{k}=\mathrm{NFC}$ treatment $(k=\mathrm{GC}, \mathrm{DCP}, \mathrm{SM}), R_{l}=\mathrm{RDP}$ treatment $(l=+\mathrm{RDP},-\mathrm{RDP}), H_{m}=$ sampling hour for ruminal measures $(m=0, \ldots, 12)$, and $\varepsilon=$ residual error. In the statistical models, interaction terms are represented by combinations of the letters used to represent variables. In all analyses, terms including cow were treated as random variables.

In situ substrate disappearance by hour and average values per cow per period for DMI, milk production, milk composition, feed efficiency, plasma urea $\mathrm{N}$, plasma glucose, plasma protein, hematocrit, plasma insulin, and ruminal measures at the lowest ruminal $\mathrm{pH}$ detected before $6 \mathrm{~h}$ postfeeding were analyzed according to the model $Y_{i j k l}=\mu+C_{i}+P_{j}+N_{k}+R_{l}+$ $N R_{k l}+\varepsilon_{i j k l}$.

Ruminal measures from the 12 -h sampling were analyzed as repeated measures with the model $Y_{i j k l m}=\mu$ $+C_{i}\left(P_{j} N_{k} R_{l}\right)+P_{j}+N_{k}+R_{l}+N R_{k l}+H_{m}+P H_{j m}+$ $N H_{k m}+R H_{l m}+N R H_{k l m}+\varepsilon_{i j k l m}$. The covariance structures tested were compound symmetry, heterogeneous compound symmetry, autoregressive, heterogeneous autoregressive, and ante-dependence. Covariance structures were selected on the basis of which gave Akaike's information criterion and Schwarz's Bayesian criterion values closest to zero. Accordingly, the autoregressive covariance structure was used for all analyses except for the ruminal fluid AA concentration, for which the heterogeneous compound symmetry structure was used. For the autoregressive models, a random statement containing the term $C_{i}\left(P_{j} N_{k} R_{l}\right)$ was included (Littell et al., 2006).

Although reported as $\mathrm{pH}$, ruminal $\mathrm{pH}$ was analyzed as hydrogen ion concentration (Murphy, 1982). Results are reported as least squares means. Orthogonal contrasts performed were corn versus citrus pulp and sucrose+molasses, and citrus pulp versus sucrose+molasses to assess the effects of NFC source and the interaction of NFC $\times$ RDP. These groupings of NFC for orthogonal contrasts were set to compare diets with NFC primarily from starch (typically the predominant NFC in lactating cow diets in the United States) with diets with the other NFC predominating. Significant orthogonal contrasts of NFC $\times$ RDP are interpreted to mean that the response of the compared NFC differed directionally in the response to RDP (e.g., with GC, milk production was greater for +RDP than for -RDP, but with citrus pulp and molasses+sucrose, milk production was greater for $-\mathrm{RDP}$ than for $+\mathrm{RDP}$ ). Significance was declared at $P \leq 0.05$ and tendency at $0.05<P<0.15$. Analyses were performed with the MIXED procedure of SAS (1999).

\section{RESULTS AND DISCUSSION}

The NFC and RDP treatments and their interaction affected various measures of performance including intake. Dry matter intake differed by NFC treatment, with cows offered GC tending to consume more than animals on the other diets and cows on SM consuming more than those on DCP diets (Table 2). The reported effects of dietary NFC complement on DMI have varied. Substitution of sugars for starch increased (Broderick et al., 2002a) or did not change (Nombekela and Murphy, 1995; Ordway et al., 2002) intake in dairy cattle. Increases in dietary concentrations of NDSF at the expense of starch increased (Lees et al., 1990; Chester-Jones et al., 1991), decreased (Valk et al., 1990; Broderick et al., 2002b), or did not affect (Van Horn et al., 1975; Leiva et al., 2000) DMI. The potential for NFC source to alter passage rate (Piwonka et al., 1994) or fiber digestibility (Heldt et al., 1999) might offer a partial answer as to why the intakes differed. In the current study, intake was unaffected by protein degradability.

\section{Milk Production and Efficiency}

Dietary NFC source, relative level of RDP, and their interaction affected production responses (Table 2). In terms of direct effects of NFC source, milk and FPCM production of cows on SM was greater than that of 
Table 2. Daily intake, milk production, milk composition, and production efficiency

\begin{tabular}{|c|c|c|c|c|c|c|c|c|c|c|c|c|c|c|}
\hline Item & \multicolumn{2}{|c|}{ Ground corn } & \multicolumn{2}{|c|}{ Citrus pulp } & \multicolumn{2}{|c|}{ Molasses+sucrose } & $\mathrm{SED}^{2}$ & \multicolumn{7}{|c|}{$P$-value } \\
\hline $\mathrm{DM}, \mathrm{kg}$ & 25.0 & 25.2 & 23.9 & 23.5 & 25.2 & 24.6 & 0.79 & 0.02 & 0.56 & 0.65 & 0.09 & 0.03 & 0.36 & 0.84 \\
\hline Milk, kg & 41.0 & 39.1 & 38.0 & 38.6 & 40.1 & 40.9 & 1.10 & 0.01 & 0.82 & 0.15 & 0.33 & $<0.01$ & 0.05 & 0.93 \\
\hline Milk fat, $\%$ & 3.35 & 3.36 & 3.40 & 3.67 & 3.45 & 3.47 & 0.11 & 0.06 & 0.15 & 0.16 & 0.03 & 0.32 & 0.33 & 0.10 \\
\hline $\mathrm{FPCM},{ }^{5} \mathrm{~kg}$ & 38.9 & 36.8 & 35.7 & 37.0 & 38.2 & 38.5 & 1.25 & 0.06 & 0.81 & 0.13 & 0.53 & 0.02 & 0.05 & 0.59 \\
\hline FPCM efficiency $^{6}$ & 1.58 & 1.47 & 1.51 & 1.59 & 1.52 & 1.56 & 0.06 & 0.74 & 0.92 & 0.03 & 0.46 & 0.83 & 0.01 & 0.55 \\
\hline $\mathrm{NE}_{\mathrm{L}}{ }^{7} \mathrm{Mcal} / \mathrm{kg}$ & 1.48 & 1.42 & 1.48 & 1.55 & 1.46 & 1.51 & 0.04 & 0.10 & 0.49 & 0.05 & 0.07 & 0.28 & 0.02 & 0.74 \\
\hline MUN, mg/dL & 13.6 & 13.2 & 13.1 & 12.1 & 12.8 & 12.2 & 0.57 & 0.05 & 0.07 & 0.66 & 0.02 & 0.88 & 0.48 & 0.58 \\
\hline SCC, linear score & 2.51 & 2.79 & 2.23 & 2.67 & 2.76 & 3.25 & 0.40 & 0.14 & 0.13 & 0.92 & 0.75 & 0.05 & 0.69 & 0.91 \\
\hline
\end{tabular}

${ }^{1}+\mathrm{RDP}=$ more ruminally degradable protein; $-\mathrm{RDP}=$ less ruminally degradable protein.

${ }^{2} \mathrm{SED}=\mathrm{SE}$ of the difference of means.

${ }^{3} \mathrm{P}=$ effect of protein degradability.

${ }^{4}$ Contrasts: NFC treatments: $1=$ corn vs. citrus + sucrose, $2=$ citrus vs. sucrose; NFC $\times \mathrm{P}$ treatments: $3=$ corn vs. citrus + sucrose, $4=$ citrus vs. sucrose.

${ }^{5} \mathrm{FPCM}=3.5 \%$ fat- and protein-corrected milk.

${ }^{6} \mathrm{FPCM}$ efficiency $=\mathrm{kg}$ of $\mathrm{FPCM} / \mathrm{kg}$ of DMI.

${ }^{7}$ Calculated from $\mathrm{NE}_{\mathrm{L}}$ requirements for actual production and maintenance divided by DMI.

cows on DCP. Milk protein production and somatic cell linear score were greater and milk fat production tended to be greater for cows consuming SM compared with those consuming DCP.

Cows consuming GC had greater milk protein production and percentages and lower milk fat percentages than did cows receiving DCP or SM. The milk composition differences between cows on GC and cows on DCP are consistent with the findings of Broderick et al. (2002b) in which cows fed high-moisture or cracked corn diets produced more milk protein than those consuming diets with dried citrus pulp. The milk protein response with diets containing more starch might be related to differences in ruminal output of microbial protein. Sannes et al. (2002) reported greater in vivo microbial protein production for lactating cows fed more starch as compared with more sucrose. Curiously, MUN was greater with GC than with the other NFC treatments. Based on the production differences, the estimated $\mathrm{NE}_{\mathrm{L}}$ content of $\mathrm{GC}$ tended to be less than that of SM or DCP.

Cows consuming diets that contained a greater proportion of protein as RDP had greater milk protein percentages and tended to have greater protein production and MUN (Table 2). Milk fat percentages tended to be less with increased RDP. Milk and FPCM production and efficiency of FPCM production were unaffected by RDP treatment. Somatic cell linear score tended to be less for cows receiving diets with greater RDP.
Effects of the interaction of NFC and RDP were intriguing (Table 2). The milk and FPCM production of cows receiving GC was greater and milk fat production tended to be greater with $+\mathrm{RDP}$ as compared with $-\mathrm{RDP}$ diets, but cows receiving DCP or SM showed greater values with $-\mathrm{RDP}$ than with +RDP diets. Efficiency of production of FPCM from DMI and estimated $\mathrm{NE}_{\mathrm{L}}$ concentration of the diets showed the same pattern of response. This suggests that the cows fed the DCP and SM diets required additional RUP for milk production, whereas the cows consuming GC had greater need for RDP. This could have been the case if there was a greater ruminal yield of microbial protein in cows consuming GC, if other nutrients became limiting before RUP, or if the degradability of corn seed protein was less than that of protein provided by the other NFC sources, increasing the need for RDP with the GC diets.

\section{Ruminal and Plasma Measures}

Both NFC and RDP influenced ruminal measures, including $\mathrm{pH}$ and organic acids that are typically considered to be derived primarily from carbohydrates. The direct effect of NFC treatment was evidenced in the tendency for the mean ruminal $\mathrm{pH}$ of cows fed SM diets to be lower than that of cows receiving DCP diets across $12 \mathrm{~h}$ of sampling (Table 3 ) and in a sampling hour $\times$ NFC interaction $(P<0.01)$, with the 


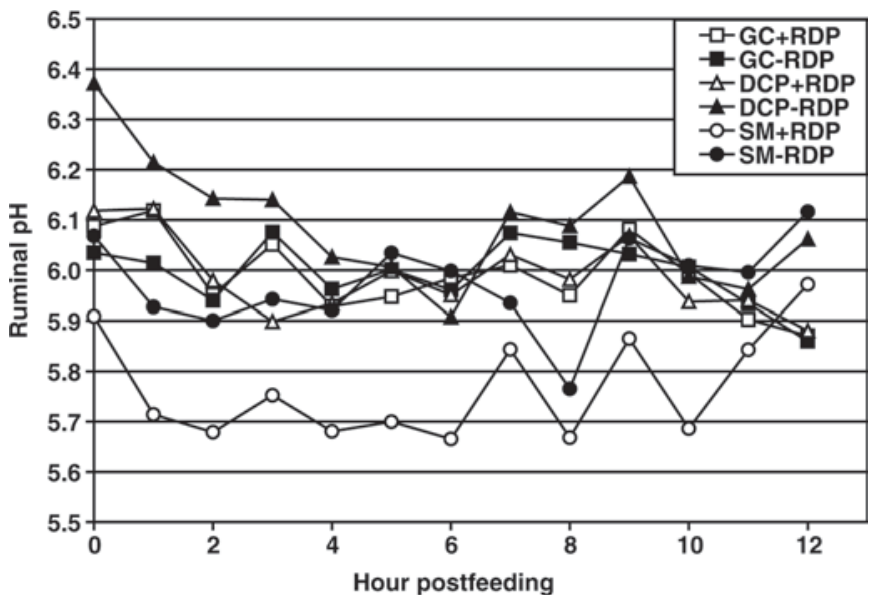

Figure 1. Ruminal pH measured through $12 \mathrm{~h}$ postfeeding. Each treatment is designated by a combination of NFC and RDP treatment abbreviations. NFC treatments: $\mathrm{GC}=$ ground corn, $\mathrm{DCP}=$ dried citrus pulp, and $\mathrm{SM}=$ sucrose + molasses; RDP treatments: $+\mathrm{RDP}$ $=$ soybean meal supplementation and $-\mathrm{RDP}=$ heat-treated soybean meal plus soybean meal supplementation. Standard error of the difference of means $=0.18$.

$\mathrm{SM}+\mathrm{RDP}$ diet giving a lower $\mathrm{pH}$ across hours than other treatments (Figure 1). The lowest ruminal $\mathrm{pH}$ values detected within $6 \mathrm{~h}$ of feeding were 5.81, 5.84, $5.94,5.91,5.56$, and 5.89 for GC+RDP, GC-RDP, $\mathrm{DCP}+\mathrm{RDP}, \mathrm{DCP}-\mathrm{RDP}, \mathrm{SM}+\mathrm{RDP}$, and SM-RDP, respectively. These $\mathrm{pH}$ values were affected by RDP and $\mathrm{NFC} \times \operatorname{RDP}(P=0.05$ for both; SE of the difference of means $=0.10)$, but NFC alone only tended to affect $\mathrm{pH}(P=0.08)$. Lowest detected ruminal $\mathrm{pH}$ was lower with SM than with DCP diets $(P=0.03)$. A significant $\mathrm{NFC} \times \mathrm{RDP}$ interaction highlights differing responses by NFC source to RDP treatments, with lower $\mathrm{pH}$ recorded for $+\mathrm{RDP}$ than for $-\mathrm{RDP}$ inclusion on $\mathrm{SM}$ diets but with little effect on $\mathrm{pH}$ by RDP treatment on the DCP diets $(P=0.02)$. The effect of protein degradability on ruminal $\mathrm{pH}$ has been shown in other in vivo studies (Aldrich et al., 1993; Carruthers and Neil, 1997), with ruminal $\mathrm{pH}$ decreasing when supply of degradable protein was increased with diets containing rapidly fermented NFC. These $\mathrm{pH}$ responses might be related to the relative amount of degradable protein altering organic acid yield (Hall and Weimer, 2007). However, across all sampling hours, total VFA were not affected by treatment (Figure 2), although they were consistently numerically greater when more RDP was fed. The total amount of carbon in VFA tended to be greater with + RDP than with $-\mathrm{RDP}$.

Among the VFA, propionate molar percentages were unaffected by dietary treatment (Table 3). Across the 12 sampling hours, DCP gave greater acetate molar percentages than did SM. Butyrate molar percentage was affected by NFC treatment, with values for SM

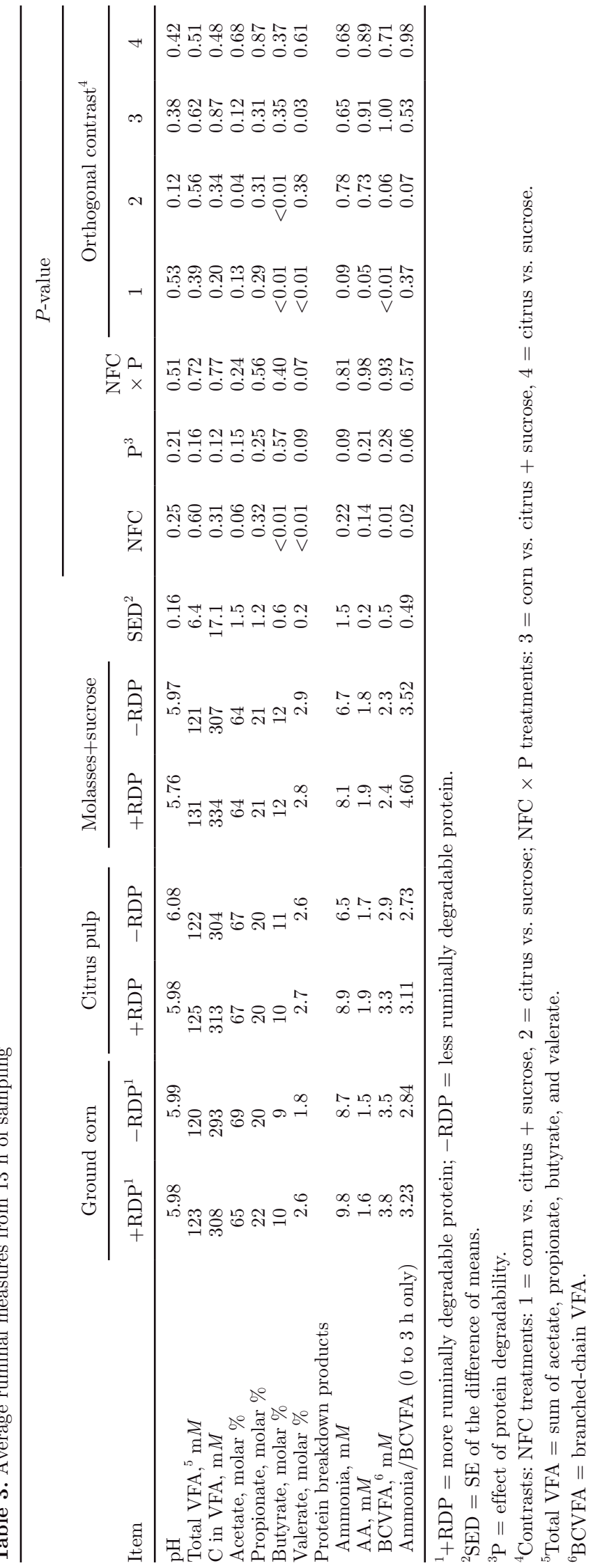

Journal of Dairy Science Vol. 93 No. 1, 2010 


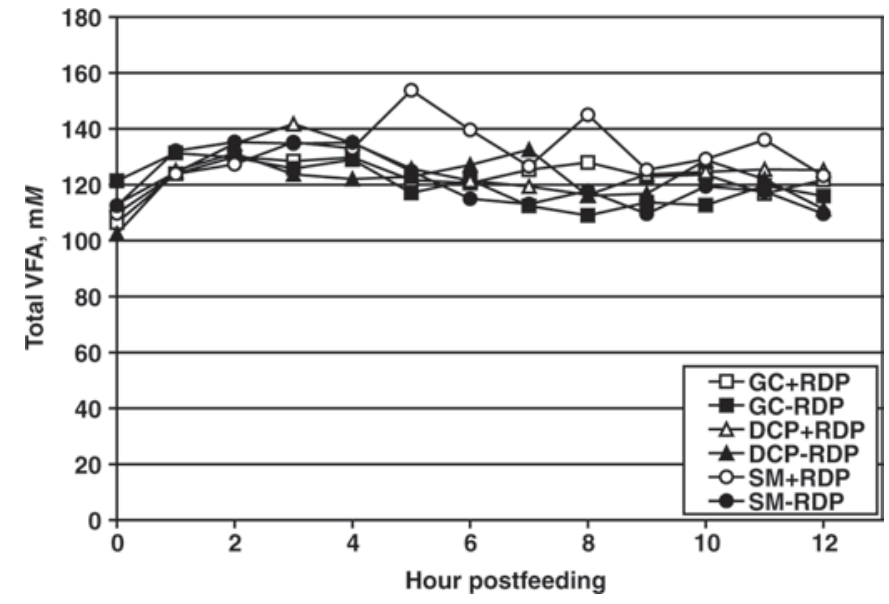

Figure 2. Total ruminal VFA concentration through $12 \mathrm{~h}$ postfeeding. Total VFA is the sum of acetate, propionate, butyrate, and valerate. Each treatment is designated by a combination of NFC and RDP treatment abbreviations. NFC treatments: $\mathrm{GC}=$ ground corn. $\mathrm{DCP}$ $=$ dried citrus pulp, and $\mathrm{SM}=$ sucrose + molasses; RDP treatments: $+\mathrm{RDP}=$ soybean meal supplementation and $-\mathrm{RDP}=$ heat-treated soybean meal plus soybean meal supplementation. Standard error of the difference of means $=6.4 \mathrm{mM}$.

greater than for DCP and values for GC less than either, possibly because of decreasing sugar content from SM through GC. Butyrate molar percentage also was affected by NFC $\times$ sampling hour $(P=0.05)$ and NFC $\times$ RDP $\times$ sampling hour $(P=0.05)$, and there was a tendency for an effect of RDP $\times$ sampling hour $(P=$ 0.08; data not shown). The findings of this study differ from in vitro fermentation research that reported increased propionate yields from starch as compared with citrus pectin but are in agreement with the findings of increased acetate concentrations from citrus pectin as compared with sucrose (Strobel and Russell, 1986). The butyrate data are consistent with studies (Strobel and Russell, 1986; Khalili and Huhtanen, 1991) in which greater ruminal butyrate concentrations were noted when feeding sugars as compared with starch.

Valerate molar percentages were lowest with GC diets as compared with DCP and SM diets, with values increasing numerically from GC to DCP to SM. They were also lower with diets containing less RDP. Valerate may be formed by degradation of carbohydrate, lactate, and other organic acids (Marounek et al., 1989), as well as from protein (Hungate, 1966). The lower protein degradability of the - RDP diets might have allowed less valerate production from protein with those diets. The increase in valerate followed the increase in dietary sugars or decrease in starch, but the role of carbohydrates here is not certain.

The protein breakdown products, AA, ammonia, and branched-chain VFA (BCVFA), all showed responses to NFC treatment but less of an effect of RDP treatment. Ruminal AA concentrations were less with GC
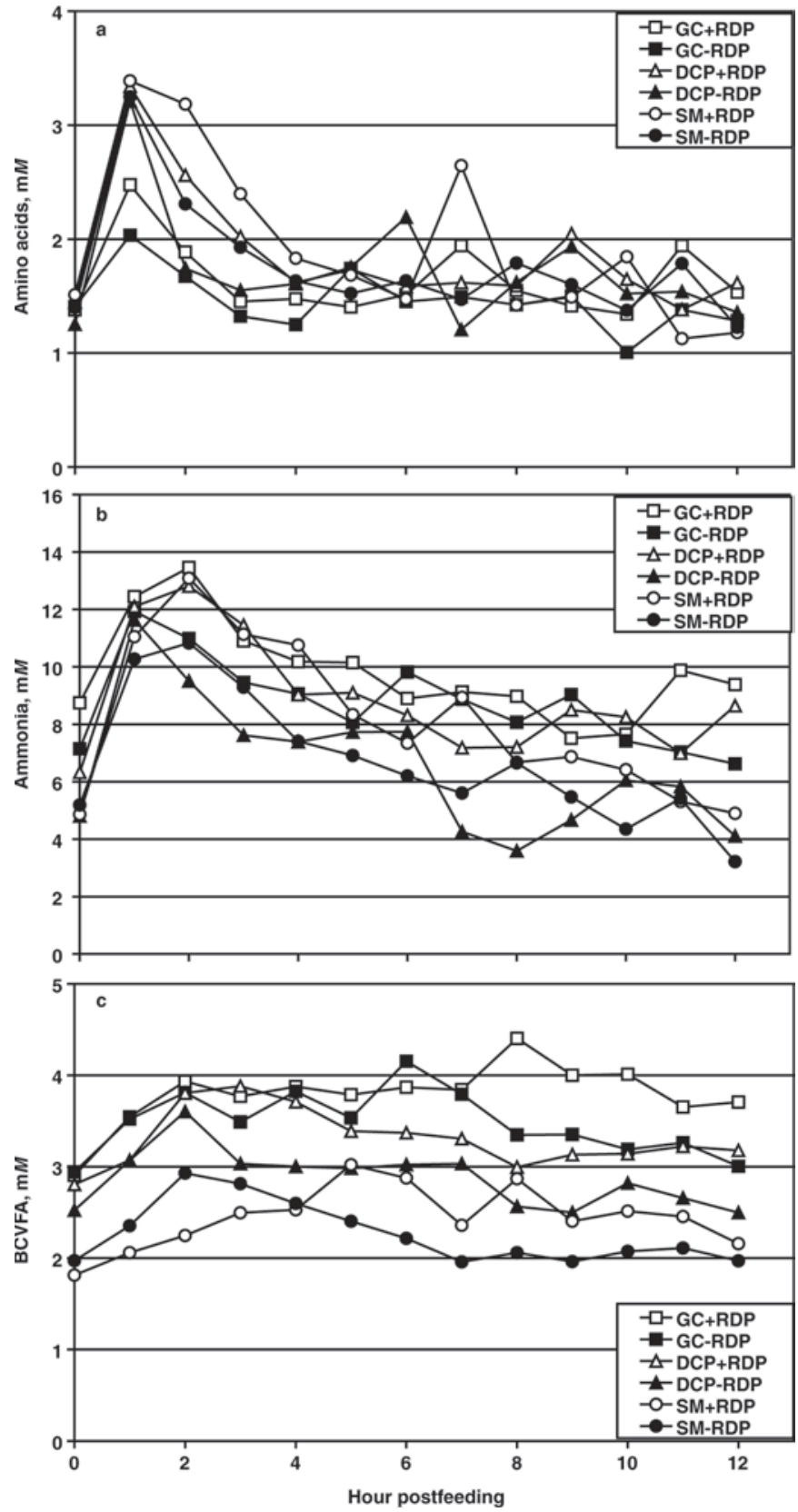

Figure 3. Protein breakdown products measured in the rumen through $12 \mathrm{~h}$ postfeeding: a) amino acids, $\mathrm{m} M, \mathrm{~b})=$ ammonia, $\mathrm{m} M$, and $\mathrm{c}$ ) = branched-chain VFA (BCVFA), $\mathrm{m} M$. Each treatment is designated by a combination of NFC and RDP treatment abbreviations. NFC treatments: $\mathrm{GC}=$ ground corn, $\mathrm{DCP}=$ dried citrus pulp, and $\mathrm{SM}=$ sucrose + molasses; RDP treatments: $+\mathrm{RDP}=$ soybean meal supplementation and $-\mathrm{RDP}=$ heat-treated soybean meal plus soybean meal supplementation. Standard error of the difference of means, $\mathrm{m} M$ : amino acids $=0.4$, ammonia $=2.1$, and $\mathrm{BCVFA}=0.5$.

than with SM and DCP and were affected by the interactions of sampling hour and both NFC and RDP $(P<$ 0.01 for both; Figure 3a). The maximal AA concentration was achieved at $1 \mathrm{~h}$ postfeeding. Ammonia concentration tended to be greater with GC than with DCP 
Table 4. Rumen in situ NDF disappearance of sorghum silage

\begin{tabular}{|c|c|c|c|c|c|c|c|c|c|c|c|c|c|c|}
\hline Hour of incubation & \multicolumn{2}{|c|}{ Ground corn } & \multicolumn{2}{|c|}{ Citrus pulp } & \multicolumn{2}{|c|}{ Molasses+sucrose } & $\mathrm{SED}^{2}$ & \multicolumn{7}{|c|}{$P$-value } \\
\hline 24 & 0.19 & 0.26 & 0.21 & 0.20 & 0.16 & 0.22 & 0.03 & 0.36 & 0.06 & 0.23 & 0.20 & 0.46 & 0.31 & 0.18 \\
\hline 30 & 0.26 & 0.32 & 0.32 & 0.26 & 0.22 & 0.27 & 0.01 & 0.02 & 0.09 & $<0.01$ & 0.06 & 0.01 & 0.02 & $<0.01$ \\
\hline 48 & 0.39 & 0.42 & 0.43 & 0.40 & 0.39 & 0.39 & 0.02 & 0.29 & 1.00 & 0.30 & 0.94 & 0.14 & 0.20 & 0.46 \\
\hline
\end{tabular}

${ }^{1}+\mathrm{RDP}=$ more ruminally degradable protein; $-\mathrm{RDP}=$ less ruminally degradable protein.

${ }^{2} \mathrm{SED}=\mathrm{SE}$ of the difference of means.

${ }^{3} \mathrm{P}=$ effect of protein degradability.

${ }^{4}$ Contrasts: NFC treatments: $1=$ corn vs. citrus + sucrose, $2=$ citrus vs. sucrose NFC $\times \mathrm{P}$ treatments: $3=$ corn vs. citrus + sucrose, $4=$ citrus vs. sucrose.

and SM, which agrees with the MUN data. Increased ruminal protein degradation, decreased microbial capture of ammonia, or increased catabolism of protein by the animal including protein in excess of requirements could give the increased ammonia concentrations. There was a tendency for ruminal ammonia to increase with increasing dietary RDP and for an effect of RDP $\times$ sampling hour $(P=0.08$; Figure $3 \mathrm{~b})$. The greatest ammonia concentrations were achieved at $1 \mathrm{~h}$ postfeeding for $-\mathrm{RDP}$ and by $2 \mathrm{~h}$ postfeeding for $+\mathrm{RDP}$ (Figure $3 \mathrm{~b})$. Provision of a greater proportion of RDP would be expected to increase ammonia concentrations and indicates that the RDP treatments did differ in ruminal degradability of protein.

The BCVFA followed a pattern similar to the butyrate results; GC had greater concentrations than DCP and $\mathrm{SM}$, and DCP tended to have greater concentrations than SM (Table 3, Figure 3c). The BCVFA were not affected by the sampling hour interactions with NFC $(P=0.67)$ or RDP $(P=0.33)$. The decrease in BCVFA with increasing dietary supply of sugars is consistent with reports of decreased BCVFA when molasses or sucrose replaced corn in diets (Broderick and Radloff, 2002; Sannes et al., 2002). In those studies, the reported decreases in BCVFA were accompanied by decreases in ruminal $\mathrm{NH}_{3}-\mathrm{N}$. In this study, ammonia concentrations were affected by the interaction of RDP with sampling hour, but BCVFA were not. Although the diets were not analyzed for AA content, dietary concentrations of branched-chain AA in the diets in this study were estimated based on NRC (2001) tabular feed composition values for the sum of isoleucine, leucine, valine, and diet compositions (Table 1). The calculated estimates indicate that concentrations in the DCP and SM diets were approximately 93 and $95 \%$ of that in the GC diets (branched-chain AA as \% of ration DM: 2.8, 2.7, 2.6, 2.6, 2.7 , and $2.6 \%$ for $\mathrm{GC}+\mathrm{RDP}, \mathrm{GC}-\mathrm{RDP}, \mathrm{DCP}+\mathrm{RDP}$,
$\mathrm{DCP}-\mathrm{RDP}, \mathrm{SM}+\mathrm{RDP}$, and SM-RDP, respectively). If these estimates are reasonable approximations of the actual diets, the differences in dietary concentrations do not explain the differences between ruminal BCVFA concentrations obtained with the GC diets as compared with the DCP and SM diets, which averaged 15 and $36 \%$ less, respectively. More conclusive work that includes AA composition and AA degradability of the feedstuffs is needed to accurately assess whether such study results involve protein or carbohydrate effects or a combination.

If both ammonia and BCVFA come from protein degradation and are largely used for protein synthesis, one would expect the ruminal ratio of the two to stay relatively constant, notwithstanding proportional changes in ruminal protein degradation and urea recycling to the rumen. The differences in ratios of ammonia to BCVFA concentrations in 0 through $3 \mathrm{~h}$ postfeeding in the current study suggest differing utilization of the BCVFA in diets with different carbohydrate complements, with increased utilization of BCVFA as compared with ammonia in diets containing more sugars. The SM diets gave the greatest values, with SM tending to be greater than DCP. The calculated estimates of branched-chain AA concentrations of the diets do not appear to provide an explanation of the differences noted, with GC diet values at 70 and $80 \%$ of those of SM diets for +RDP and $-\mathrm{RDP}$, respectively. There is work that indicates that BCVFA can be incorporated into microbial fatty acids (Allison et al., 1962) and can be found in greater concentrations in liquid-associated bacteria, perhaps such as those that use sugars, than in solid-associated bacteria (Bauchart et al., 1990). This use of BCVFA for other than de novo synthesis of AA could dissociate their utilization from that of ammonia. There was a tendency for BCVFA values for - RDP to be less than those for + RDP. The interactions with sampling hour 


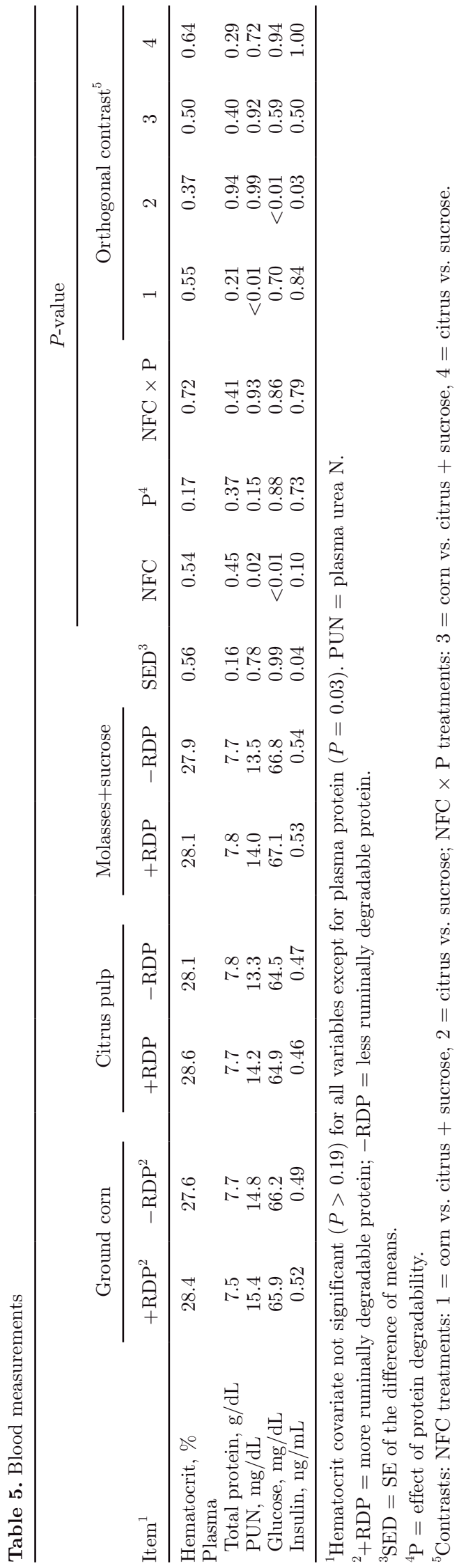

showed an effect of NFC source $(P=0.02)$ but no effect of $\operatorname{RDP}(P=0.36)$.

In situ disappearance of sorghum silage NDF was affected by NFC, RDP, and their interaction, but the effects varied by hour of incubation, with the most significant differences noted at $30 \mathrm{~h}$ (Table 4). At 24 $\mathrm{h}, \mathrm{NDF}$ disappearance values for $-\mathrm{RDP}$ tended to be greater than those for +RDP. At $30 \mathrm{~h}, \mathrm{GC}$ and SM had greater values for $-\mathrm{RDP}$ than for $+\mathrm{RDP}$, whereas the reverse effect of RDP was true for DCP. At 48 $\mathrm{h}$, DCP tended to have greater values than did SM, and no separate effect of RDP was noted. These results support the concept that ruminal NDF disappearance is not just a function of the inherent characteristics of the feedstuff but might be affected by characteristics of the entire diet beyond diet effects on ruminal $\mathrm{pH}$. These results are in contrast to studies in which digestibility of NDF increased with sugar supplementation in vivo (Piwonka et al., 1994; Heldt et al., 1999) or in which addition of RDP resulted in improvements in NDF digestibility across different types of carbohydrate supplementation (Heldt et al., 1999). The results are in agreement with digestibility increases noted when feeding pectin-rich feeds (Ben-Ghedalia et al., 1989; Van Vuuren et al., 1993) and decreases in rate of NDF digestion when fermenting glucose (a sugar), attributed to a proteinaceous inhibitor (Piwonka and Firkins, 1996). The low $\mathrm{pH}$ noted on SM+RDP might have had a negative effect on ruminal NDF digestion. Alternatively, the decreased BCVFA noted for SM as compared with other NFC treatments might have made this nutrient more limiting for microbes such as fiber users that use BCVFA and ammonia for protein production. Protein degradation products have been shown to be stimulatory to fibrolytic bacteria (Stewart and Bryant, 1988).

\section{Blood Measures}

Plasma protein concentration and hematocrit (Table 5 ) were not affected by treatment and were not used to adjust the concentrations of metabolites in the blood. Plasma urea $\mathrm{N}$ followed the same pattern as MUN and ruminal ammonia, tending to increase when dietary RDP was increased and with GC greater than with SM and DCP. Plasma glucose and insulin concentrations were greater for cows fed SM as compared with cows fed DCP. Increases in blood glucose have been noted previously in dry cows with the inclusion of $2.7 \%$ sucrose in the diets (Ordway et al., 2002).

\section{CONCLUSIONS}

Changes in dietary NFC source and degradability of dietary protein altered intake, lactation performance, 
blood, and ruminal measures in lactating dairy cows. Relative concentration of dietary RDP can interact with NFC source to give different directions of response for ruminal $\mathrm{pH}$, fiber disappearance, ruminal protein breakdown products, milk production, energy content of diets, and feed efficiency, and this interaction is not currently taken into account in determining how to meet animal nutrient requirements (NRC, 2001). With the potential for these direct effects of NFC source, relative dietary RDP concentration, and their interactions to alter animal performance from that predicted with current diet formulations, we recommend that work be undertaken to gain more comprehensive, quantitative understanding of these effects, including the differing nutritional characteristics of the various nonfiber carbohydrates. This will allow the establishment of guidelines for diet formulation that promote efficient lactation performance by dairy cows.

\section{REFERENCES}

Aldrich, J. M., L. D. Muller, G. A. Varga, and L. C. Griel Jr.. 1993. Nonstructural carbohydrate and protein effects on rumen fermentation, nutrient flow, and performance of dairy cows. J. Dairy Sci. 76:1091-1105.

Allison, M. J., M. P. Bryant, I. Katz, and M. Keeney. 1962. Metabolic function of branched-chain volatile fatty acids, growth factors for uminococci. II. Biosynthesis of higher branched-chain fatty acids and aldehydes. J. Bacteriol. 83:1084-1093.

Bach Knudsen, K. E. 1997. Carbohydrate and lignin contents of plant materials used in animal feeding. Anim. Feed Sci. Technol. 67:319-338.

Bauchart, D., F. Legay-Carmier, M. Doreau, and B. Gaillard. 1990. Lipid metabolism of liquid-associated and solid-adherent bacteria in rumen contents of dairy cows offered lipid supplemented diets. Br. J. Nutr. 63:563-578.

Ben-Ghedalia, D., E. Yosef, J. Miron, and Y. Est. 1989. The effects of starch- and pectin-rich diets on the quantitative aspects of digestion in sheep. Anim. Feed Sci. Technol. 24:289-298.

Broderick, G. A., N. D. Luchini, W. J. Radloff, G. A. Varga, and V. A. Ishler. 2002a. Effect of replacing dietary starch with sucrose on milk production in lactating dairy cows. Pages 116-118 in U.S. Dairy Forage Research Center 2000-2001 Research Report. USDFRC, Madison, WI.

Broderick, G. A., D. R. Mertens, and R. Simons. 2002b. Efficacy of carbohydrate sources for milk production by cows fed diets based on alfalfa silage. J. Dairy Sci. 85:1767-1776.

Broderick, G. A., and W. J. Radloff. 2002. Effects of replacing dietary high moisture corn with dried molasses on production of dairy cows. Pages 106-109 in U.S. Dairy Forage Research Center 20002001 Research Report. USDFRC, Madison, WI.

Broderick, G. A., P. Udén, M. L. Murphy, and A. Lapins. 2004. Sources of variation in rates of in vitro ruminal protein degradation. J. Dairy Sci. 87:1345-1359.

Carruthers, V. R., and P. G. Neil. 1997. Milk production and ruminal metabolites from cows offered two pasture diets supplemented with non-structural carbohydrate. N. Z. J. Agric. Res. 40:513-521.

Chester-Jones, H., M. D. Stern, H. M. Metwally, J. G. Linn, and D. M. Ziegler. 1991. Effects of dietary protein-energy interrelationships on Holstein steer performance and ruminal bacterial fermentation in continuous culture. J. Anim. Sci. 69:4956-4966.

Fegeros, K., G. Zervas, S. Stamouli, and E. Apostolaki. 1995. Nutritive value of dried citrus pulp and its effect on milk yield and milk composition of lactating ewes. J. Dairy Sci. 78:1116-1121.
Gochman, N., and J. M. Schmitz. 1972. Application of a new peroxide indicator reaction to the specific automated determination of glucose with glucose oxidase. Clin. Chem. 18:943-950.

Goering, H. K., and P. J. Van Soest. 1970. Agriculture Handbook No. 379: Forage Fiber Analyses: Apparatus, Reagents, Procedures, and Some Applications. ARS-USDA, Washington, DC.

Hall, M. B. 2002. Working with sugars (and molasses). Pages 149-161 in Proc. 13th Ann. Florida Ruminant Nutrition Symp., Gainesville, FL. University of Florida, Gainsville.

Hall, M. B., and C. Herejk. 2001. Differences in yields of microbial crude protein from in vitro fermentation of carbohydrates. J. Dairy Sci. 84:2486-2493.

Hall, M. B., W. H. Hoover, J. P. Jennings, and T. K. Miller Webster. 1999. A method for partitioning neutral detergent-soluble carbohydrates. J. Sci. Food Agric. 79:2079-2086.

Hall, M. B., and P. J. Weimer. 2007. Sucrose concentration alters fermentation kinetics, products, and carbon fates during in vitro fermentation with mixed ruminal microbes. J. Anim. Sci. 85:1467-1478.

Heldt, J. S., R. C. Cochran, G. L. Stokka, C. G. Farmer, C. P. Mathis, E. C. Titgemeyer, and T. G. Nagaraja. 1999. Effects of different supplemental sugars and starch fed in combination with degradable intake protein on low-quality forage use by beef steers. J. Anim. Sci. $77: 2793-2802$.

Hungate, R. E. 1966. The Rumen and Its Microbes. Academic Press Inc., New York, NY.

Khalili, H., and P. Huhtanen. 1991. Sucrose supplements in cattle given grass silage based diet: Digestion of organic matter and nitrogen. Anim. Feed Sci. Technol. 33:247-261.

Lees, J. A., J. D. Oldham, W. Haresign, and P. C. Garnsworthy. 1990. The effect of patterns of rumen fermentation on the response by dairy cows to dietary protein concentration. Br. J. Nutr. 63:177186.

Leiva, E., M. B. Hall, and H. H. Van Horn. 2000. Performance of dairy cattle fed citrus pulp or corn products as sources of neutral detergent-soluble carbohydrates. J. Dairy Sci. 83:2866-2875.

Littell, R. C., G. A. Milliken, W. W. Stroup, R. D. Wolfinger, and O. Schabenberger. 2006. SAS for Mixed Models. SAS Inst. Inc., Cary, NC.

Malestein, A., A. T. van't Klooster, R. A. Prins, and G. H. M. Counotte. 1984. Concentrate feeding and ruminal fermentation. 3. Influence of concentrate ingredients on $\mathrm{pH}$, on DL-lactic acid concentration in the rumen fluid of dairy cows and on dry matter intake. Neth. J. Agric. Sci. 32:9-21.

Malven, P. V., H. H. Head, R. J. Collier, and F. C. Buonomo. 1987. Periparturient changes in secretion and mammary uptake of insulin and concentrations of insulin and insulin-like growth factors in milk of dairy cows. J. Dairy Sci. 70:2254-2262.

Mansfield, H. R., M. D. Stern, and D. E. Otterby. 1994. Effects of beet pulp and animal by-products on milk yield and in vitro fermentation by rumen microorganisms. J. Dairy Sci. 77:205-216.

Marounek, M., K. Fliegrova, and S. Bartos. 1989. Metabolism and some characteristics of ruminal strains of Megasphaera elsdenii. Appl. Environ. Microbiol. 55:1570-1573.

Marsh, W. H., B. Fingerhut, and H. Miller. 1965. Automated and manual direct methods for the determination of blood urea. Clin. Chem. 11:624-627.

Murphy, M. R. 1982. Analyzing and presenting pH data. J. Dairy Sci. 65:161-163.

Nocek, J. E. 1988. In situ and other methods to estimate ruminal protein and energy digestibility. J. Dairy Sci. 71:2051-2069.

Nombekela, S. W., and M. R. Murphy. 1995. Sucrose supplementation and feed intake of dairy cows in early lactation. J. Dairy Sci. $78: 880-885$.

NRC. 2001. Nutrient Requirement of Dairy Cattle. 7th rev. ed. Natl. Acad. Sci., Washington, DC.

Ordway, R. S., V. A. Ishler, and G. A. Varga. 2002. Effects of sucrose supplementation on dry matter intake, milk yield, and blood metabolites of periparturient Holstein dairy cows. J. Dairy Sci. $85: 879-888$. 
Piwonka, E. J., and J. L. Firkins. 1996. Effect of glucose fermentation on fiber digestion by ruminal microorganisms in vitro. J. Dairy Sci. 79:2196-2206.

Piwonka, E. J., J. L. Firkins, and B. L. Hull. 1994. Digestion in the rumen and total tract of forage-based diets with starch or dextrose supplements fed to Holstein heifers. J. Dairy Sci. 77:1570-1579.

Sannes, R. A., M. A. Messman, and D. B. Vagnoni. 2002. Form of rumen-degradable carbohydrate and nitrogen on microbial protein synthesis and protein efficiency of dairy cows. J. Dairy Sci. 85:900-908.

SAS. 1999. The SAS System for Windows, Release 6.12. SAS Inst Inc., Cary, NC.

Soeldner, J. S., and D. Slone. 1965. Critical variables in radioimmunoassay of serum insulin using double antibody technique. Diabetes 14:771-777.

Solomon, R., L. E. Chase, D. Ben-Ghedalia, and D. E. Bauman. 2000 The effect of nonstructural carbohydrate and addition of full fat extruded soybeans on the concentration of conjugated linoleic acid in the milk fat of dairy cows. J. Dairy Sci. 83:1322-1329.

Stewart, C. S., and M. P. Bryant. 1988. The rumen bacteria. Pages 10 72 in The Rumen Microbial Ecosystem. P. N. Hobson, ed. Elsevier Appl. Sci., London, UK.
Strobel, H. J., and J. B. Russell. 1986. Effect of pH and energy spilling on bacterial versus corn starch or beet pulp fiber diet effects of digestion and intestinal amino acids in dairy cows. J. Dairy Sci. $76: 2692-2700$.

Tyrrell, H. F., and J. T. Reid. 1965. Prediction of the energy value of cow's milk. J. Dairy Sci. 48:1215-1223.

Valk, H., H. W. Klein Poelhuis, and H. J. Wentink. 1990. Effects of fibrous and starchy carbohydrates in concentrates as supplements in a herbage-based diet for high-yielding dairy cows. Neth. J. Agric. Sci. 38:475-486.

Van Horn, H. H., S. P. Marshall, C. J. Wilcox, P. F. Randel, and J. M. Wing. 1975. Complete rations for dairy cattle. III. Evaluation of protein percent and quality, and citrus pulp-corn substitutions. J. Dairy Sci. 58:1101-1108.

Van Soest, P. J., J. B. Robertson, and B. A. Lewis. 1991. Methods for dietary fiber, neutral detergent fiber, and nonstarch polysaccharides in relation to animal nutrition. J. Dairy Sci. 74:3583-3597.

Van Vuuren, A. M., C. J. Van Der Koelen, and J. Vroons-De Bruin. 1993. Ryegrass versus corn starch or beet pulp fiber diet effects of digestion and intestinal amino acids in dairy cows. J. Dairy Sci. 76:2692-2700. 